\title{
Interpretation of spatiotemporal gravity changes accompanying the earthquake of 21 August 2017 on Ischia (Italy)
}

Giovanna BERRINO ${ }^{1, *}$ (D) Peter VAJDA ${ }^{2}$ (D), Pavol ZAHOREC ${ }^{2}$ (D), Antonio G. CAMACHO ${ }^{3}$ iD, Vincenzo DE NOVELLIS ${ }^{1,4}$, Stefano CARLINO ${ }^{1}$ D, Juraj PAPČO ${ }^{5}$ (D), Eliana BELLUCCI SESSA ${ }^{1}$ (D), Richard CZIKHARDT ${ }^{5}$ (D)

${ }^{1}$ Osservatorio Vesuviano, Istituto Nazionale di Geofisica e Vulcanologia (INGV), Sezione di Napoli, Napoli, Italy; e-mails: giovanna.berrino@ingv.it, stefano.carlino@ingv.it, eliana.bellucci@ingv.it

${ }^{2}$ Earth Science Institute, Slovak Academy of Sciences, Bratislava, Slovakia; e-mails: Peter.Vajda@savba.sk, zahorec@savbb.sk

${ }^{3}$ Institute of Geosciences (CSIC-UCM), Madrid, Spain; e-mail: antonio.camacho@mat.ucm.es

${ }^{4}$ IREA, Italian National Research Council (CNR), Napoli, Italy; e-mail: vincenzo.denovellis@cnr.it

${ }^{5}$ Department of Global Geodesy and Geoinformatics, Slovak University of Technology, Bratislava, Slovakia; e-mails: juraj.papco@stuba.sk, richard.czikhardt@stuba.sk

updated version based on Corrigendum: published 2022-01-25,

doi: 10.31577/congeo.2021.51.4.3.c

Abstract: We analyse spatiotemporal gravity changes observed on the Ischia island (Italy) accompanying the destructive earthquake of 21 August 2017. The 29 May 2016 to 22 September 2017 time-lapse gravity changes observed at 18 benchmarks of the Ischia gravimetric network are first corrected for the gravitational effect of the surface deformation using the deformation-induced topographic effect (DITE) correction. The co-seismic DITE is computed by Newtonian volumetric integration using the Toposk software, a high-resolution LiDAR DEM and the co-seismic vertical displacement field derived from Sentinel-1 InSAR data. We compare numerically the DITE field with its commonly used Bouguer approximation over the island of Ischia with the outcome that the Bouguer approximation of DITE is adequate and accurate in this case. The residual gravity changes are then computed at gravity benchmarks by correcting the observed gravity changes for the planar Bouguer effect of the elevation changes at benchmarks over the same period. The residual gravity changes are then inverted using an inversion approach based on model exploration and growing source bodies, making use of the Growth-dg inversion

\footnotetext{
*corresponding author, e-mail: giovanna.berrino@ingv.it
} 
tool. The found inversion model, given as subsurface time-lapse density changes, is then interpreted as mainly due to a co-seismic or post-seismic disturbance of the hydrothermal system of the island. Pros and weak points of such interpretation are discussed.

Key words: volcano geodesy, 4D microgravimetry, gravimetric inverse problem, coseismic time-lapse gravity change, DITE, Growth inversion

\section{Introduction}

Ischia is a densely inhabited volcanic island with a long eruptive history, with the latest eruption in $1302 \mathrm{AD}$ (Sbrana et al., 2018), characterized by significant asymmetric resurgence of a caldera block (Capuano et al., 2015; Selva et al., 2019). Ischia volcano belongs to the Neapolitan volcanic system. It is located to the SW of the Campi Flegrei caldera, and of the volcanic islands of Procida and Vivara. Ischia volcano has been the site of a large number of eruptions in historical times, and of other interdependent hazardous phenomena associated with its magmatic system. It contains an active hydrothermal system (Di Napoli et al., 2011). The island experienced on 21 August $2017 \mathrm{a} \mathrm{Mw}=3.9$ earthquake that caused 2 fatalities, several tens of injured, and substantial damages mainly to the village of Casamicciola Terme, located in the northern part of the island. Ischia is one of the most evident, better studied and known cases of intra-calderic resurgence. With its uplift of the order of about 900-1100 m, very rarely recognized in other volcanic areas, it represents a unique case. The resurgent area has a polygonal shape resulting from the reactivation of regional faults and the activation of faults directly related to volcano-tectonism (Acocella and $\mathrm{Fu}$ niciello 1999).

The INGV-OV (Istituto Nazionale di Geofisica e Vulcanologia - Osservatorio Vesuviano) manages a ground deformation monitoring network of Ischia Island which integrates continuous (cGPS and tiltmetric networks) and repeat-campaign (levelling, GPS and gravimetric networks) measurements (Berrino et al., 1985; Sepe et al. 2007; Berrino and Corrado, 2008; Del Gaudio et al., 2011; De Martino et al., 2011). Several studies based on the DInSAR measurements are also available (Manzo et al., 2006; Vilardo et al., 2009; Castaldo et al., 2017).

Since 1983 gravity is monitored using relative gravimetry (Berrino et al., 1984) at a network (Fig. 1) consisting of stations close to levelling bench- 


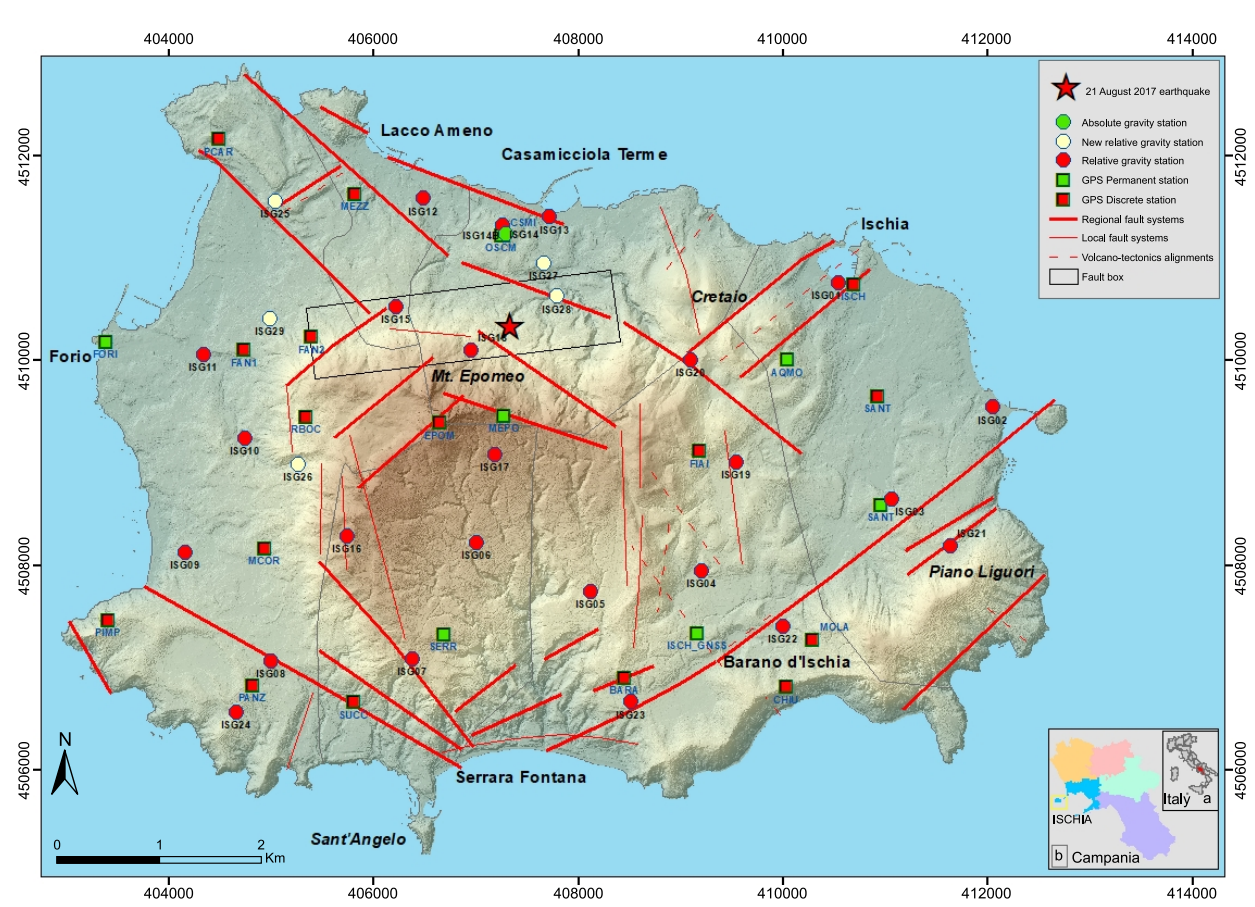

Fig. 1. The structural and tectonic settings of the Ischia island showing the epicentre and fault plane of the earthquake of 21 August 2017 and the gravimetric and deformation networks (the symbols are defined in the legend). The geographic location is shown in insets (a) and (b).

marks. An absolute gravity station was also established in 1994 in Casamicciola, where the gravity value is periodically measured. The relative network is linked to the absolute gravity station in Napoli (Berrino, 1995), chosen as the reference outside the island, that is also a main node of the "National Zero Order Gravity Net" (IZOGN_1995), which will be also included in the planned new "Italian Reference Gravity Network - G0_2020" (Berrino et al., 1995; Berrino, 2020). Since 1983, generally no significant gravity changes have been observed over the whole island. Statistically significant gravity variations, if observed, are generally located in very limited areas, suggesting that they may be associated with local effects rather than with volcanic behavior. No changes between Napoli and the ISCG01 station on Ischia (cf. Fig. 1), adopted as local reference, have been evidenced during all the field surveys. Statistically significant gravity variations affecting the whole 
island with a well-defined spatial pattern have been observed occasionally during sporadic time intervals since 1999 with the maximum values centred at Mount Epomeo (Pingue et al., 2000, Berrino and Corrado, 2008).

All the deformation measurements at Ischia in the last 30 years (levelling since 1987, GPS since 1998 and SAR since 1992) show a general vertical subsidence of almost the whole island with velocities between 1 and $5 \mathrm{~mm} /$ year, with higher values (up to about $1 \mathrm{~cm} /$ year) along the central-western sector of the Mt. Epomeo structure (Del Gaudio et al., 2011; De Martino et al., 2011; Manzo et al., 2006; Castaldo et al., 2017). The GPS station located on the top of Mt Epomeo (EPOM, Fig. 1), shows a vertical subsidence velocity of about $9 \mathrm{~mm} /$ year in the period 1998-2010 (De Martino et al., 2011). In the NW part of Mt Epomeo (Lacco Ameno), the area involved in the landslide occurred during the 1883 earthquake also shows relatively high velocity rate of subsidence, $>5 \mathrm{~mm} /$ year, recorded in the period 1992-2003 by DInSAR (see Fig. 6 of Manzo et al., 2006). The continuous tiltmetric borehole network of Ischia island (Ricco et al., 2018) shows a predominant NNW tilting direction in 2015-2017 time span, which is consistent with the general differential subsidence trend of the island (Ricco et al., 2017). The ground deformation pattern recorded on Ischia cannot be explained by a typical volcanic source deflation (e.g., a Mogi model). Some have attributed the subsidence detected by levelling measurements to crack closure processes along two main ENE-WSW and E-W pre-existing faults, which represent the preferred $\mathrm{CO}_{2}$ degassing pathway of the hydrothermal system beneath Monte Epomeo (Sepe et al., 200\%). More recently, Castaldo et al. (2017) developed a model of Ischia DInSAR measurements for the period 1992-2010 explained by the coupling effects of crust rheology and the gravitational loading of the volcano, while Trasatti et al. (2019) have shown that magma degassing from a cooling shallow magma body is possibly responsible for subsidence at Ischia.

The strongest seismic event instrumentally recorded at Ischia occurred on 21 August 2017 (Mw 3.9 - Md 4.0, Carlino et al., 2021) and was followed by a seismic sequence of almost 20 recorded earthquakes, with significantly lower magnitude. The damage level and its distribution (Azzaro et al., 2017) agree with the historical observations of low magnitude high intensity events (Carlino et al., 2010; Carlino et al., 2021). The most relevant damages affected a narrow area of Casamicciola Terme (Azzaro et al., 2017) that shows 
different fractures on ground, infrastructure, roads, and terrain. The highest damaged area was completely evacuated after the event. Widespread sliding phenomena of drywalls were also observed, as well as modest gravitational phenomena and small landslides in volcanoclastic deposits. The observed co-seismic effects cover a total length of about $2 \mathrm{~km}$ between the Fango (Lacco Ameno), to the west, and Bagni (Casamicciola), to the east, for a total area of about $2.5 \mathrm{~km}^{2}$ (EMERGEO Working Group, Nappi et al., 2017; Nappi et al., 2018).

Ground displacements caused by the earthquake were detected using DInSAR, GPS and tilt measurements. Following the main seismic event, two stations of the Ischia cGPS network showed a co-seismic deformation. The cGPS station on Monte Epomeo (MEPO) showed a displacement of about $1.5 \mathrm{~cm}$ in NNW direction and the cGPS station of Casamicciola Terme (OSCM) moved about $1 \mathrm{~cm}$ toward NNE. Only at MEPO station a slight subsidence of about $1 \mathrm{~cm}$ was observed (De Novellis et al., 2018; Devoti et al., 2018). The DInSAR measurements showed a localized $\left(\sim 1 \mathrm{~km}^{2}\right)$ subsidence up to $4 \mathrm{~cm}$ in an area south of Casamicciola Terme. The shape of the displacement pattern shows an E-W alignment, which is in good agreement with aftershock epicentres distribution (De Novellis et al., 2018). Also two tiltmetric stations recorded a co-seismic tilt (Ricco et al., 2017).

With a multiparametric approach (seismic, GPS and DInSAR data), the seismogenetic source can be described as an E-W striking, vertical or S-dipping normal fault (De Novellis et al., 2018). The joint inversion revealed the fault plane parameters and the associated slip distribution with values up to $14 \mathrm{~cm}$ located at the centre of the fault plane at a depth of about $800 \mathrm{~m}$, which is rather shallow and provides a possible explanation, together with local amplification effects, to the damage caused by this relatively low magnitude earthquake (De Novellis et al., 2018). Recently, Braun et al. (2018) and Calderoni et al. (2019) proposed more complex rupture processes, with a normal faulting displacement accompanied by underground phenomena, also potentially connected to the hydrothermal system. Braun et al. (2018) suggest a complex rupture process, with an initial shallow normal-faulting event that triggered a subsequent shallow underground collapse. 


\section{Time-lapse gravity changes related to the 2017 earthquake}

By repeat-campaign observations on the benchmarks of the network over a period 29/05/2016-22/09/2017 covering the 2017 destructive earthquake, the spatiotemporal gravity changes were acquired. These are not truly coseismic gravity changes, as they span a time-lapse of roughly 16 months, but they capture also the gravitational signal of the co-seismic structural changes. Figure 2 shows the spatiotemporal gravity changes interpolated from observed benchmark values.

Relative gravity measurements were collected with the LaCoste \& Romberg model D (LCR-D\#85) relative gravimeter. Field measurements were carried out following appropriate procedures to obtain high quality data (Berrino et al., 2013). Each gravity difference between couples of stations was independently measured following a strict procedure, the so called "Passo del Pellegrino" procedure (A-B-A-B-A or A-B-A-B-C-B-C-D-C-D... or A-B-A-B-C-B-C-B-A-D-C-D-C-D-A...). Each gravity point was occupied

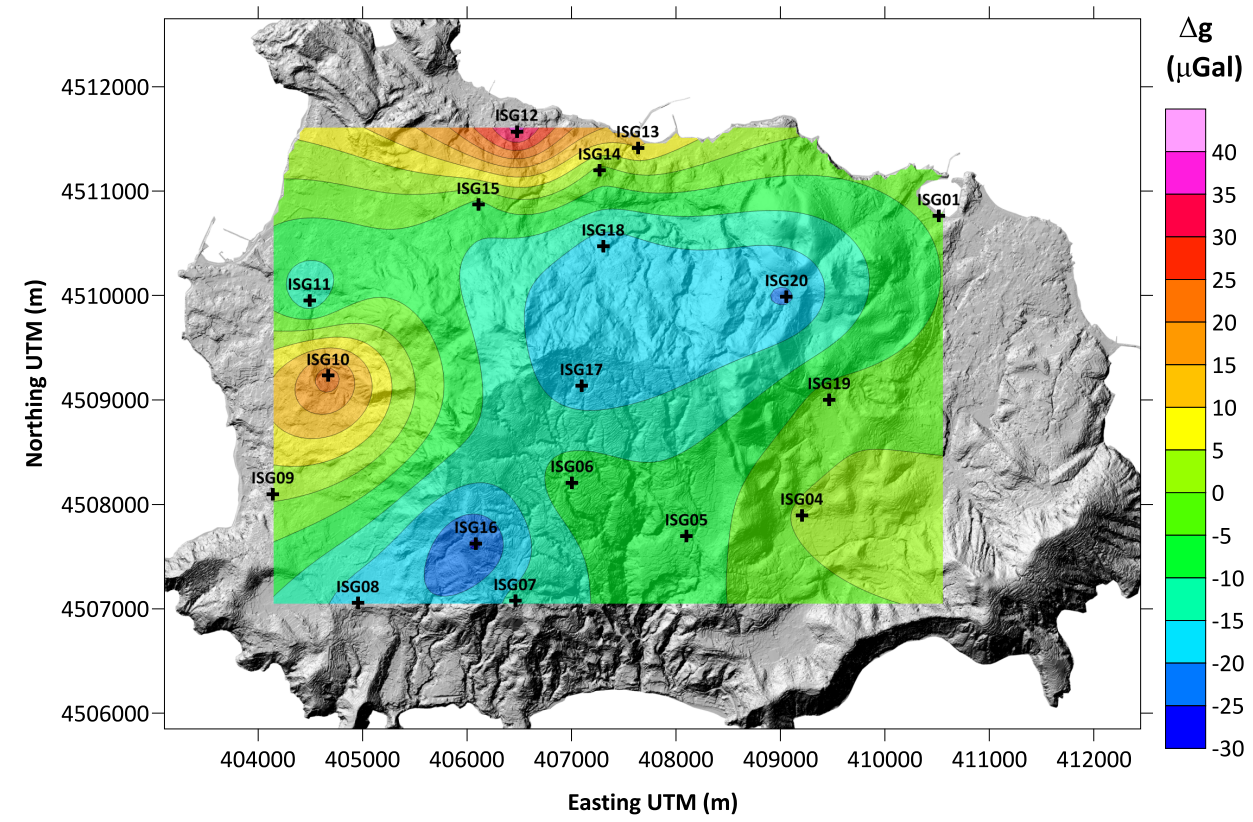

Fig. 2. Observed spatiotemporal gravity changes ( $\mu$ Gal) over the period 29/05/2016$22 / 09 / 2017$ draped over the shaded relief of Ischia. Crosses show positions of benchmarks of the gravity network. 
several times, at least twice, at different times to better detect and remove the instrumental drift and the unrecoverable tares (steps on the drift curve) due to shocks during the transport. At each occupation several readings at different time intervals were performed till the instrument reached its stability; the final value was taken from the average of at least three or four readings. The tie between the island and the terra-firma were carried out with hydrofoils or ferry using the same procedures as described above.

The readings were corrected for the effects of earth tides and air pressure. The solid earth-tide effect was removed according to Tamura's gravity potential catalogue (Tamura, 1987), the tide being calculated using the latitude dependent tidal parameters based on non-hydrostatic Earth model (Dehant et al., 1999) and provided by Tsoft software (Van Camp and Vauterin, 2005).

The atmospheric pressure effect was removed from the gravity readings using a mean admittance coefficient of $-0.35 \mu \mathrm{Gal} / \mathrm{hPa}$ (Warburton and Goodkind, 1977; Spratt, 1982), pressure being simultaneously measured at each occupation of each gravity station through portable barometers (the Delta Ohm, mod. HD 2114B.0) with a resolution of $0.1 \mathrm{hPa}$ and accuracy of $0.3 \mathrm{hPa}$ ).

At each station, only the cleaned readings recurring with the same value or at least with a difference of few $\mu \mathrm{Gal}(1-3 \mu \mathrm{Gal})$ were accepted; their average value was used to detect and remove the instrumental drift. Finally, the mean value obtained by the repeated occupation at each station was used to compute the gravity difference between each pair of stations. In this way we obtained gravity differences with an error no greater than $\pm 5-6 \mu \mathrm{Gal}$, and we also have had a redundancy of repeated observations under different conditions. The ties among the stations were carried out in order to create a base net formed by several loops with misclosures adjusted by means of a least square method.

Since we do not have appropriate data to compute reliable hydrological correction, we do not correct the gravity changes for the hydrological effect (effect of hydrological changes). This does not mean that we neglect the hydrological effect. We treat the changes in the hydrological situation (temporal density changes due to hydrological variations) as part of the sought solution. In other words, hydrological sources remain part of the inversion solution (model). 


\subsection{Processing of gravity change data}

Spatiotemporal (time-lapse) gravity changes observed in volcanic areas are complex composite signals. The gravity changes $(\Delta g)$ observed at benchmarks $(P)$ must be first corrected for all signal components other than those associated with the studied volcanic or other geodynamic processes. Among these are atmospheric and tidal effects, instrumental and survey design effects, and hydrological effects (e.g., Battaglia et al., 2008; Hemmings et al., 2016; Carbone et al., 2017; Fernández et al., 2017; Van Camp et al., 2017). Their treatment was described in the above section.

If elevation changes (surface vertical displacements) accompany gravity changes then the gravitational effect of the surface deformation must be carefully accounted for. To extract the gravitational signal component related only to the subsurface mass or density changes of the source of the geodynamic event $\left(\Delta g^{\mathrm{M}}\right)$, several gravitational effects must still be removed, including that of the topographic deformation. This removal of unwanted signal components constitutes the computation of residual gravity changes $\Delta g^{\text {res }}$ (Vajda et al., 2019 and references therein):

$\Delta g^{\mathrm{res}}(P) \equiv \Delta g(P)-\Delta g^{\mathrm{DITE}}(P)-\Delta g^{\text {idef }}(P)=\Delta g^{\mathrm{M}}(P)$.

The individual signal components, evaluated at the gravity benchmark $(P)$ on the (post-deformation) topographic surface are as follows. The $\Delta g^{\text {DITE }}$ term is the gravitational effect of the deformation of free surface, called the deformation-induced topographic effect (DITE). Since the surface deformation is observable, this term can be computed and removed from observed gravity changes. Its computation is addressed further below. The $\Delta g^{\text {idef }}$ term is the attraction of inner deformations within the crust. Since inner deformations are not directly observable, this term cannot be computed directly and removed as a correction from observed gravity changes. It can be only estimated or modelled.

The DITE is due to two causes: the vertical displacement of the gravity benchmark in the ambient gravity field (the so called gradient effect or freeair effect) and the attraction of the deformed surficial topographic masses, i.e. masses enclosed between the pre- and post-deformation surfaces (the so to speak Newtonian effect). Therefore, the DITE has two constituents (Vajda et al., 2019, Eq. (2)): 
$\Delta g^{\mathrm{DITE}}(P) \equiv \Delta g^{\mathrm{FAE}}(P)+\Delta g^{\mathrm{TDE}}(P)$.

The first term $\left(\Delta g^{\mathrm{FAE}}\right)$ is the free-air effect (FAE) based on the true (in situ) vertical gradient of gravity $(\Gamma)$ observed at the benchmark, by which the elevation change $(\Delta h)$ of a benchmark is multiplied:

$\Delta g^{\mathrm{FAE}}(P)=\Gamma(P) \Delta h(P)$.

The second term is the Newtonian effect, the so called topographic deformation effect (TDE) that must be computed numerically by a 3D Newtonian volumetric integration (ibid). Vajda et al. (2019) have derived an alternate expression for the numerical evaluation of DITE defined by Eq. (2), which does not require the availability (knowledge) of the true (in situ) vertical gradient of gravity (VGG) on benchmarks:

$\Delta g^{\operatorname{DITE}}(P)=\Gamma_{0} \Delta h(P)+\left[a^{\mathrm{T} *}\left(P^{*}\right)-a^{\mathrm{T}}(P)\right]$.

The first term here is a gradient effect, this time based on the constant theoretical (normal) free-air gradient $\left(\Gamma_{0}=-308.6 \mu \mathrm{Gal} / \mathrm{m}, 1 \mu \mathrm{Gal} / \mathrm{m}=\right.$ $10^{-8} \mathrm{~s}^{-2}$ ) abbreviated as FAG. The second term, the square brackets term, differs from the TDE term $\left(\Delta g^{\mathrm{TDE}}\right)$ of Eq. (2). The square brackets term is the difference between the attraction of the post-deformation topographic masses evaluated on the post-deformation topographic surface $\left(a^{\mathrm{T} *}\left(P^{*}\right)\right)$ and the attraction of the pre-deformation topographic masses evaluated on the pre-deformation topographic surface $\left(a^{\mathrm{T}}(P)\right)$. The topographic masses are those bound between sea level and the earth surface. A constant reference density $\left(\rho_{0}\right)$ of the topographic masses is adopted in evaluating this term. It is evaluated by numerical volumetric Newtonian integration, which requires a high-quality digital elevation model (DEM) of the study area, ideally with horizontal resolution less than $10 \mathrm{~m}$ and high vertical accuracy, a correct choice of the topographic reference density $\left(\rho_{0}\right)$, and the availability of the vertical displacement field in areal form (grid), such as from DInSAR.

For the numerical evaluation of the square brackets term in Eq. (4) we use the software Toposk (Zahorec et al., 2017) which calculates the attraction of topographic masses up to the distance of the outer limit of zone $\mathrm{O}$ $(166.7 \mathrm{~km})$ of the Hayford-Bowie system (Hayford and Bowie, 1912). Different resolution DEMs (increasing towards the evaluation point) and different 
representations (with the option of using planar or spherical approach) of the volumetric elements are used within different integration zones of the Hayford-Bowie system.

If the vertical displacements are only available as scattered point data, i.e. elevation changes observed at gravity benchmarks, the DITE can be evaluated only in one of its two admissible approximations, which are the limiting cases for the DITE behavior (Vajda et al., 2019). The first is the Bouguer approximation (BCFAG-DITE) that uses the so-called planar "Bouguer corrected FAG" (BCFAG, denoted below as $\Gamma_{\mathrm{B}}$ ), cf. (e.g., Berrino et al., 1984, 1992; Rymer, 1994):

$\Delta g^{\operatorname{DITE}}(P) \approx \Gamma_{\mathrm{B}} \Delta h(P), \quad$ where $\quad \Gamma_{\mathrm{B}}=\left[\Gamma_{0}+2 \pi G \rho_{0}\right]$,

where $G$ is the Newton constant and $\Gamma_{0}$ is the constant theoretical FAG. The second admissible approximation of DITE is the "normal FAE" (nFAEDITE):

$\Delta g^{\operatorname{DITE}}(P) \approx \Gamma_{0} \Delta h(P)$.

In both the above approximations, the DITE field is just a scaled vertical displacement field, i.e., displacement field multiplied by a constant value of a gravity gradient.

\subsection{Co-seismic DITE field and its Bouguer approximation}

First we analyse how accurately the Bouguer representation of DITE (Eq. (5)) would approximate the DITE field numerically evaluated using Eq. (4) on the island of Ischia. We perform this analysis on the 2017 co-seismic vertical displacement field. To compute the DITE field we use a DEM derived from LiDAR data with a resolution of $1 \mathrm{~m}$ for the numerical integration within the inner zone. The DEM data, in UTM WGS84 coordinate system, were downloaded from the official website Città Metropolitana di Napoli and then processed in environment GIS (ArcGIS (C) rel. 10.6, ESRI, 2011).

The coseismic vertical displacement field adopted to compute the DITE was derived from Sentinel-1 (S1) DInSAR data by combining the information relevant to the pixels common to the following ascending (ASC) and descending (DESC) line-of-sight (LOS) displacement maps: ASC 17/08/201729/08/2017, ASC 16/08/2017-28/08/2017, ASC 05/08/2017-23/08/2017, 
ASC and DESC 10/08/2017-22/08/2017, DESC 16/08/2017-28/08/2017 (De Novellis et al., 2018). The vertical displacement field is shown in Fig. 3.

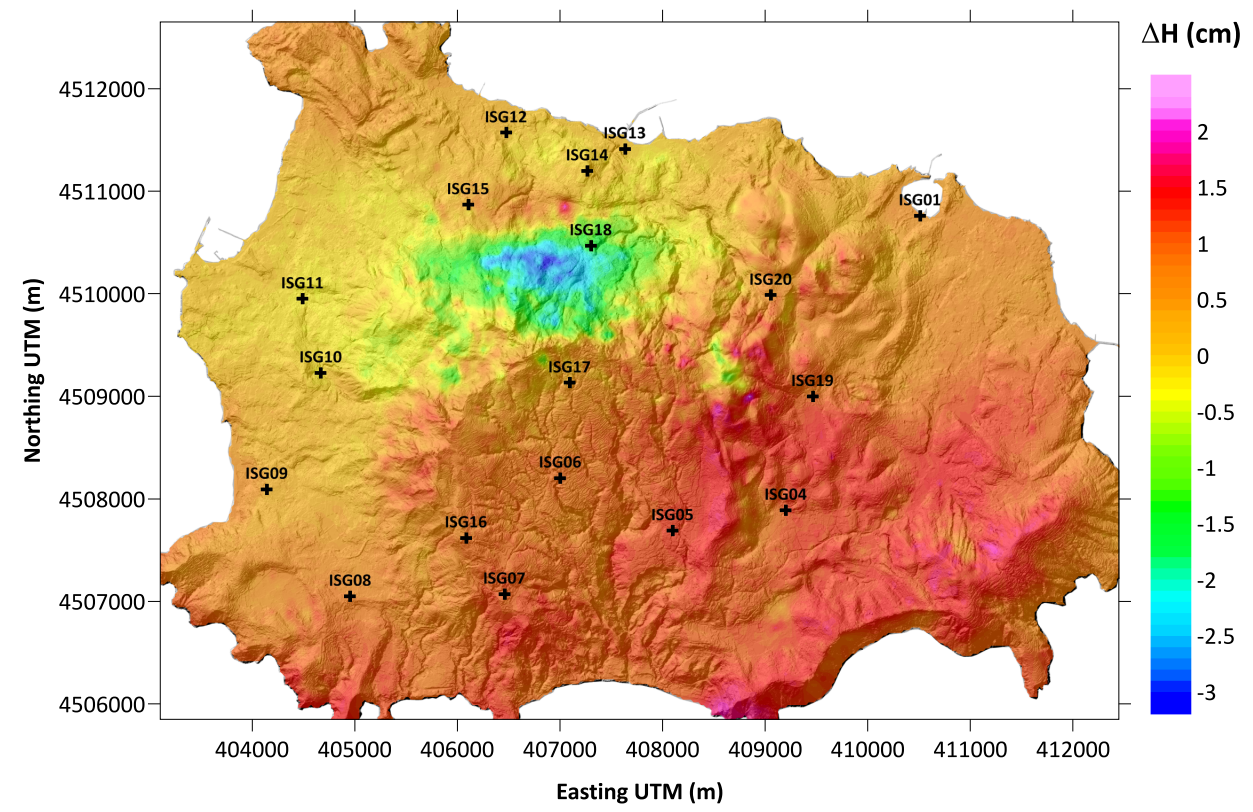

Fig. 3. The 2017 coseismic vertical displacement field $(\mathrm{cm})$ draped over shaded relief of Ischia.

The coseismic DITE field was computed (Eq. (4)) using the vertical displacement field shown in Fig. 3. We did not account for the gravitational effect of seafloor deformation. There are no data on seafloor deformation available for our study period, so it is not possible to account for it. However, the significant surface deformation focuses around the fault location, and vanishes towards the shore, so there seems to be no need to account for seafloor deformation. For details regarding the numerical procedure based on the Toposk program we refer the reader to (Vajda et al., 2019, 2021). The coseismic DITE field is shown in Fig. 4.

We note that the DITE field, and thus also the DITE correction at all gravity benchmarks, is below the level of $8 \mu \mathrm{Gal}$, which is within the error budget of the observed gravity changes estimated at the level of $10 \mu \mathrm{Gal}$. Still, as it is a systematic effect, which can be numerically evaluated, the DITE should be computed and applied as a correction to observed gravity 


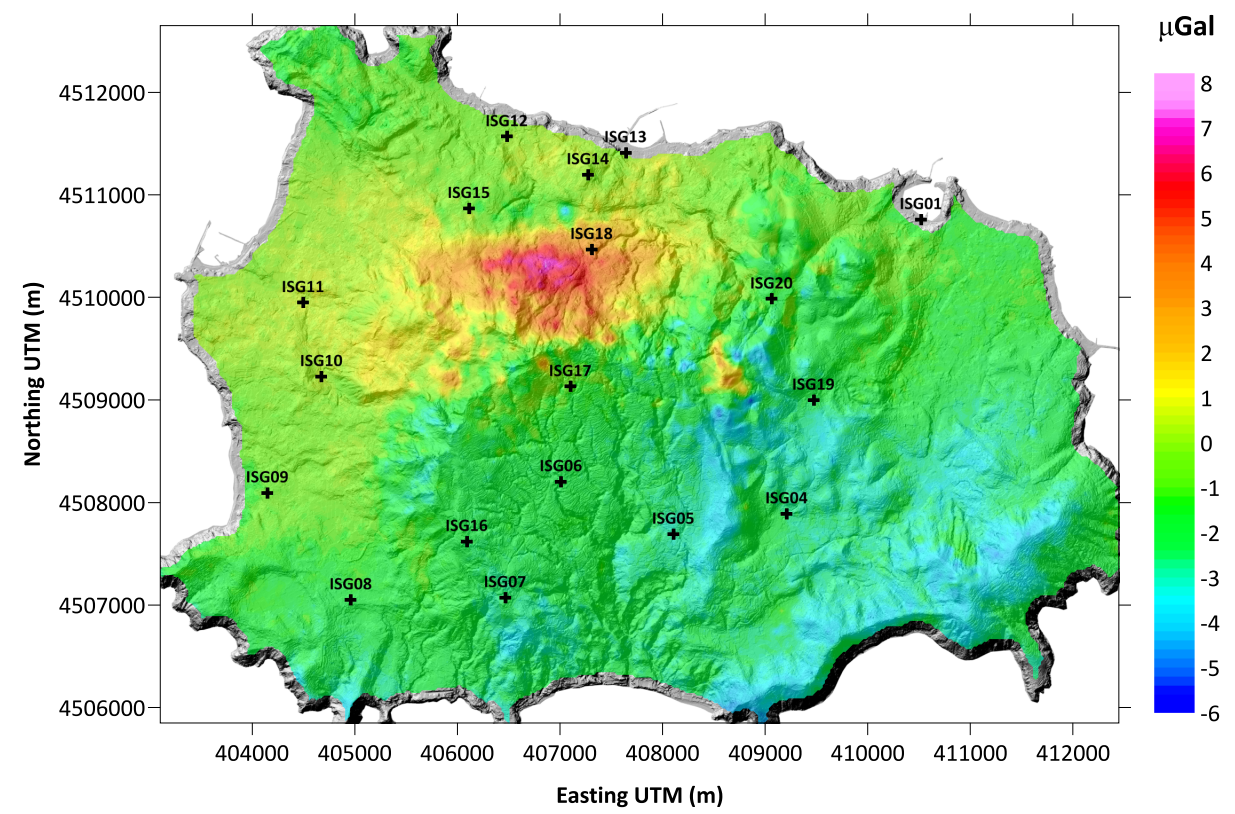

Fig. 4. The co-seismic DITE field $(\mu \mathrm{Gal})$ respective to the surface deformation of Fig. 3.

changes.

In order to assess how well would the Bouguer approximation of DITE (Eq. (5)) perform on Ischia for the surface deformation accompanying the 2017 earthquake, we compute the BCFAG-DITE field and compare it with the DITE field, both respective to the co-seismic vertical displacement field shown in Fig. 3. Both fields are computed with the density value of $2200 \mathrm{~kg} / \mathrm{m}^{3}$ (Berrino et al., 1998). This density value results in the BCFAG value of $-216.6 \mu \mathrm{Gal} / \mathrm{m}$. We show the difference between the two fields in Fig. 5.

The differences in our study area have a minimum of $-1.0 \mu \mathrm{Gal}$, maximum of $+1.0 \mu \mathrm{Gal}$, mean of $-0.1 \mu \mathrm{Gal}$, and RMS of $0.2 \mu \mathrm{Gal}$. We conclude that the 2017 co-seismic DITE field on Ischia can be adequately, i.e. accurately enough, approximated by its Bouguer representation (Eq. (5)).

Consequently, we compute the DITE correction, needed to compile residual gravity changes at gravity benchmarks, by multiplying the elevation changes at benchmarks, respective to the period 29/05/2016 to $22 / 09 / 2017$, 


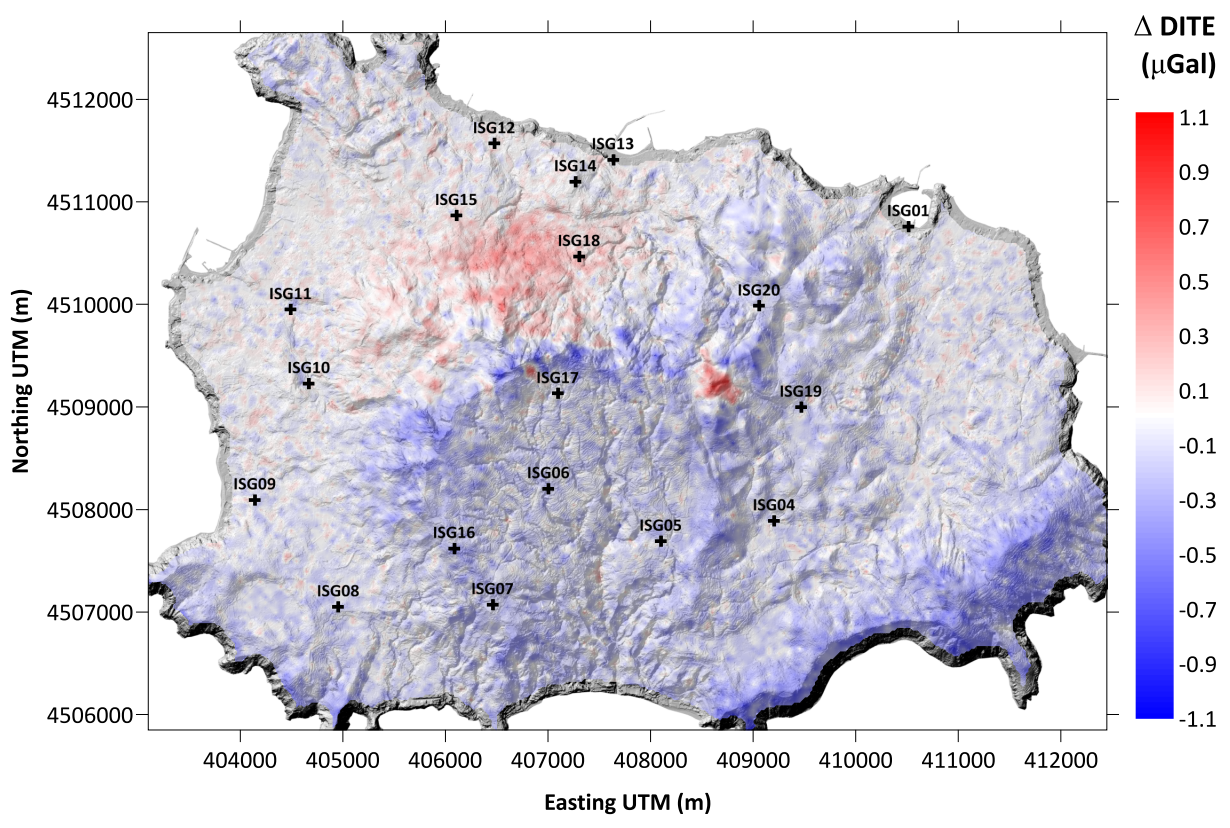

Fig. 5. The difference between the DITE field and its Bouguer approximation ( $\mu \mathrm{Gal})$.

by the constant value of BCFAG equal to $-216.6 \mu \mathrm{Gal} / \mathrm{m}$.

\subsection{Residual spatiotemporal gravity changes $29 / 05 / 2016$ to $22 / 09 / 2017$}

The residual gravity changes at benchmarks of the gravimetric network were computed by correcting the observed spatiotemporal gravity changes for the DITE in its Bouguer approximation (Eq. (5)) using elevation changes at benchmarks over the period $29 / 05 / 2016$ to $22 / 09 / 2017$. The gravity changes have not been corrected for hydrological effects due to ground water level changes and soil moisture changes. The hydrological signal thus remains present in the interpreted residual gravity changes and therefore the hydrological sources are part of the inversion solution. We did not account for the gravitational effect of landslides associated with the 2017 earthquake. The gravitational effect of a landslide would pose only a very local effect on the nearest gravity station, a site effect, which would not be correlated over several gravity stations. 
Figure 6 shows the residual gravity changes, related to the period 29/ 05/2016-22/09/2017, interpolated from benchmark values. These scattered point data given on the topographic surface, i.e. residual gravity changes at benchmarks, are next inverted using the Growth-dg inversion tool.

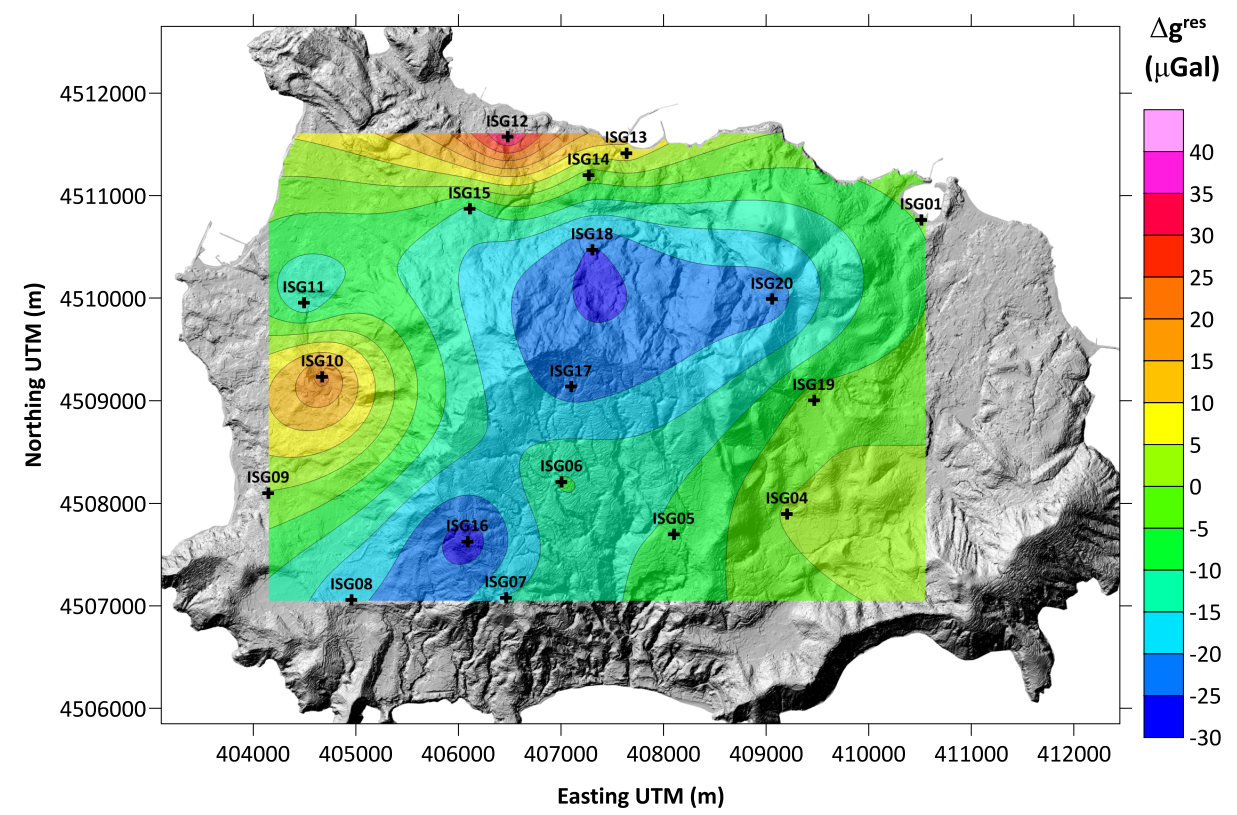

Fig. 6. Residual spatiotemporal gravity changes ( $\mu \mathrm{Gal}$ ) over the period $29 / 05 / 2016$ to $22 / 09 / 2017$.

The accuracy of the observed gravity values (in each repeat survey) is estimated at $5 \mu \mathrm{Gal}$, and of the gravity changes at the level of $7 \mu \mathrm{Gal}$. The accuracy of the elevation changes at benchmarks is estimated at $1 \mathrm{~cm}$. Consequently the accuracy of the DITE correction (in Bouguer approximation) is estimated at $2 \mu \mathrm{Gal}$. If considering also uncertainty of the density determination for the Bouguer gradient (BCFAG), a conservative estimate for the accuracy of the DITE correction (in Bouguer approximation) is about $3 \mu \mathrm{Gal}$. Finally the accuracy of the residual gravity changes (those corrected for DITE) is roughly $8 \mu \mathrm{Gal}$, conservatively estimated at the level of $10 \mu \mathrm{Gal}$. The accuracy of the remaining corrections (drift, atmospheric, tidal) does not compromise the estimated level of accuracy of $10 \mu \mathrm{Gal}$. The effect of hydrological changes is not treated as correction, it remains in the residual 
gravity changes and participates in the subject of inversion and interpretation, i.e. hydrological sources are part of the sought sources. The signal of the residual gravity changes peaks at the level of $30 \mu \mathrm{Gal}$, so the noise is at the level of one third of the signal magnitude.

The residual spatiotemporal gravity changes relate to the period of roughly 16 months (29/05/2016 to 22/09/2017) and hence are not purely coseismic. In addition to the co-seismic signal component, they may also contain a component due to hydrological changes, as well as that due to ongoing long-term subsidence over the given period.

\section{Growth inversion of residual gravity changes}

To invert the residual gravity changes at benchmarks, we apply a "Growth" inversion approach (Camacho et al., 2011, 2021a), modified to working with sparse micro-gravity changes of low signal-to-noise ratio (Camacho et al., 2021b, Vajda et al., 2021), which makes no a priori assumptions about the source geometry. The application of the "Growth-dg" inversion tool enables to obtain, in a nearly automatic and non-subjective mode, a 3D model of subsurface temporal density changes given by means of aggregation of parallelepiped cells. An iterative exploratory method is used to fill in the cells with incremental density changes. The Growth iterative inversion procedure is based on minimizing the misfit between observed and model gravity data constrained by minimizing the total subsurface temporal mass change. This regularization forces the model solutions towards compact sources with least possible structural complexities. The weight between minimizing the observations misfit and the compactness of the sources is controlled by a balance parameter $(\lambda)$. Low $\lambda$ values result in a very tight fit to the input gravity data and a complex aggregation of cells, many small source bodies, and too much detail in the solution that may be unrealistic, given the sparse and inaccurate input microgravity data. Such solutions are considered as "overfitting" the input data. High $\lambda$ values result in more compact solutions with a smaller number of source bodies, but a poorer fit to the input gravity data. The running screen of the Growth inversion process is shown in Fig. 7.

The Growth inversion was run on the residual gravity changes at 18 gravity benchmarks. The subsurface was partitioned into roughly 100,000 


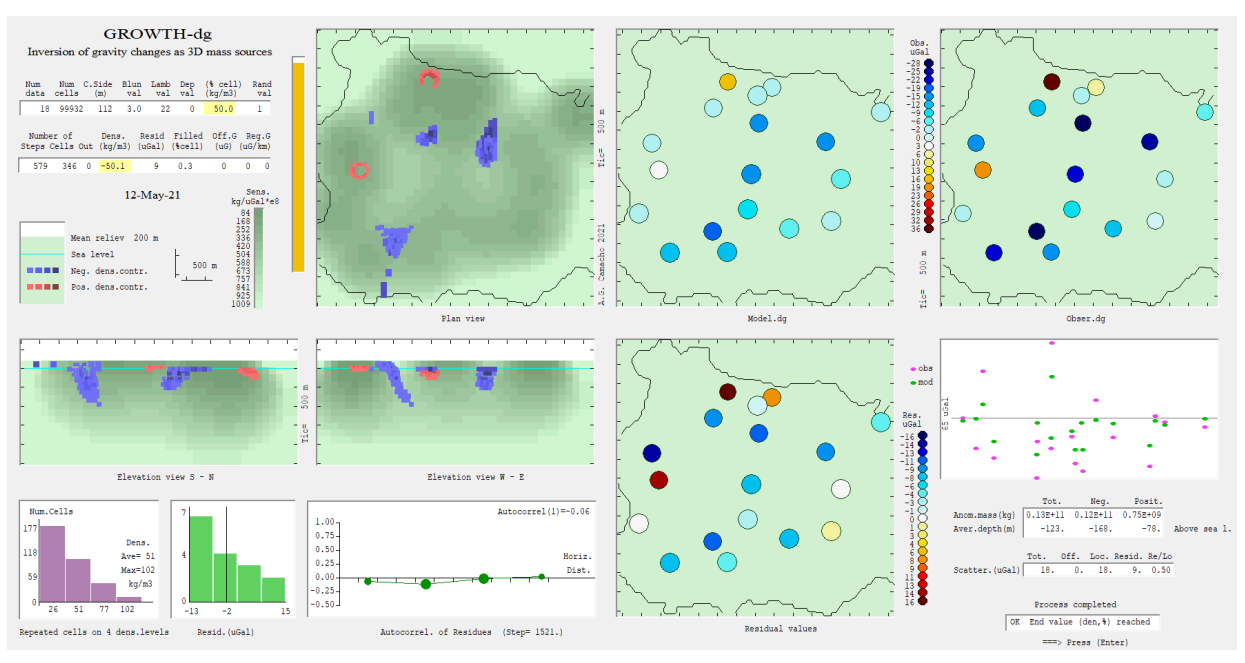

Fig. 7. The running screen of the Growth inversion process showing the inversion run parameters (top left panel), the growing source bodies in map view and $\mathrm{W}-\mathrm{E}$ and $\mathrm{S}-\mathrm{N}$ side views, showing the histogram of the anomalous source density at 4 selected levels, the histogram of residuals, the autocorrelation function, the observed, modelled and residual gravity values at gravity benchmarks, the distribution of the residuals, and the parameters of the obtained model sources.

right-rectangular cells of an average size of $112 \mathrm{~m}$ (their size growing with depth). The balance factor of the inversion run was chosen as $\lambda=22$. The inversion was performed seeking sources with target average (positive and negative) anomalous density equal to $50 \mathrm{~kg} / \mathrm{m}^{3}$, being populated by cells with discrete anomalous density values of plus or minus 26, 51, 77 and $102 \mathrm{~kg} / \mathrm{m}^{3}$. The process terminated after 579 iterations upon populating $0.3 \%$ of all subsurface cells (346 filled cells), resulting in the r.m.s of the misfit (adjustment residuals) of $9 \mu \mathrm{Gal}(\min =-13$, $\max =+15$, mean $=$ $-2 \mu \mathrm{Gal}$ ). The total mass change of the negative sources is $1.2 \mathrm{e}+10 \mathrm{~kg}$ with average depth of $168 \mathrm{~m}$ b.s.l. Selected horizontal and vertical sections of the resulting inversion model are shown in Fig. 8, while a top view and two lateral views at the 3D model are shown in Fig. 9.

\section{Interpretation of inversion results}

Our inversion model (Fig. 9) is composed of three main source bodies of 


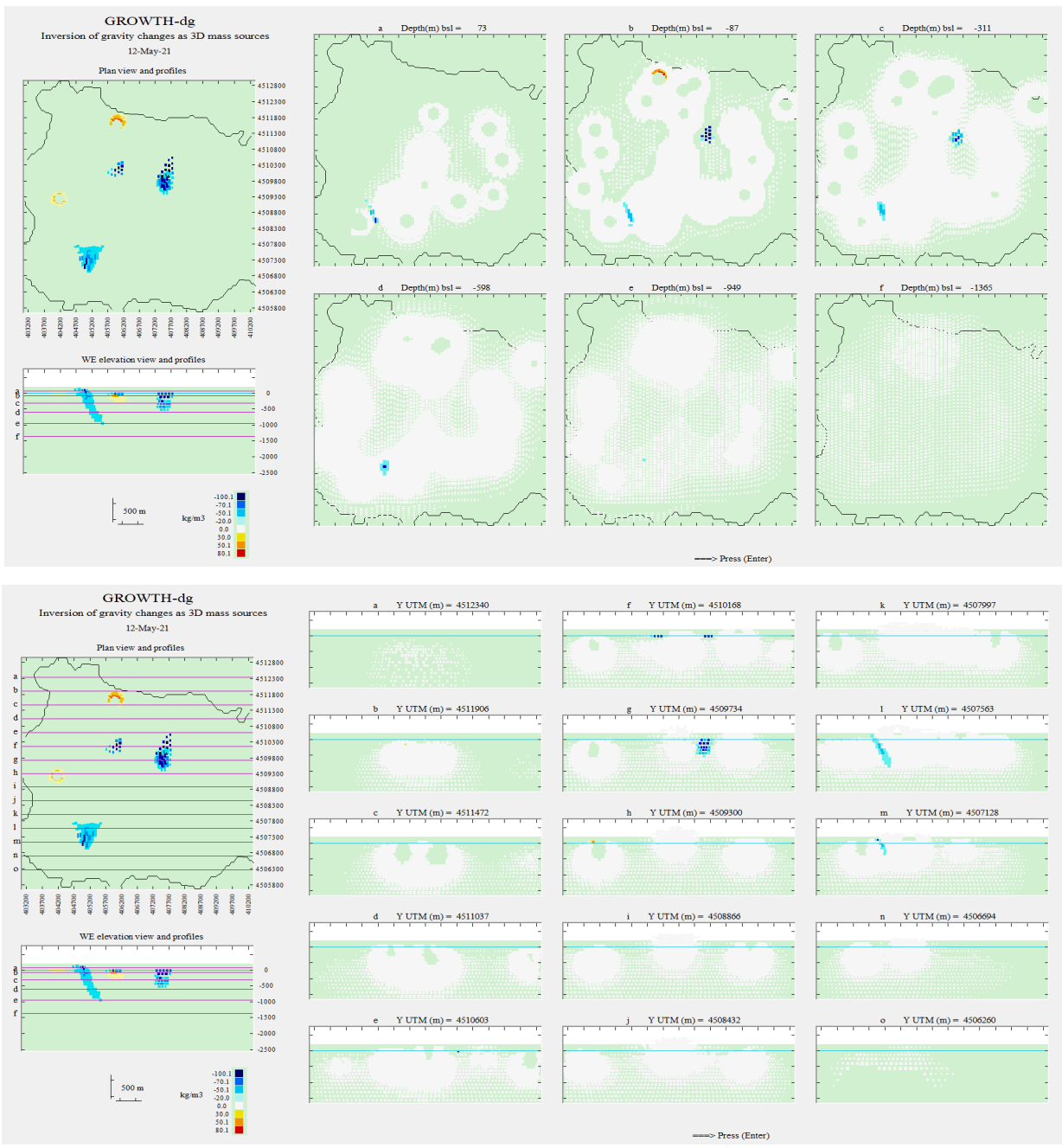

Fig. 8. Horizontal slices (top) and vertical W-E sections (bottom) of the resulting Growth model.

negative time-lapse density changes. Two of them are in the north and are spatially correlated with the 2017 earthquake fault. They are connected with the top of the fault plane and extend southwards, above the south dipping fault plane and away from it, at shallow depths between sea level and about $800 \mathrm{~m}$ b.s.l., also with a south dip. The NE source is stronger in 

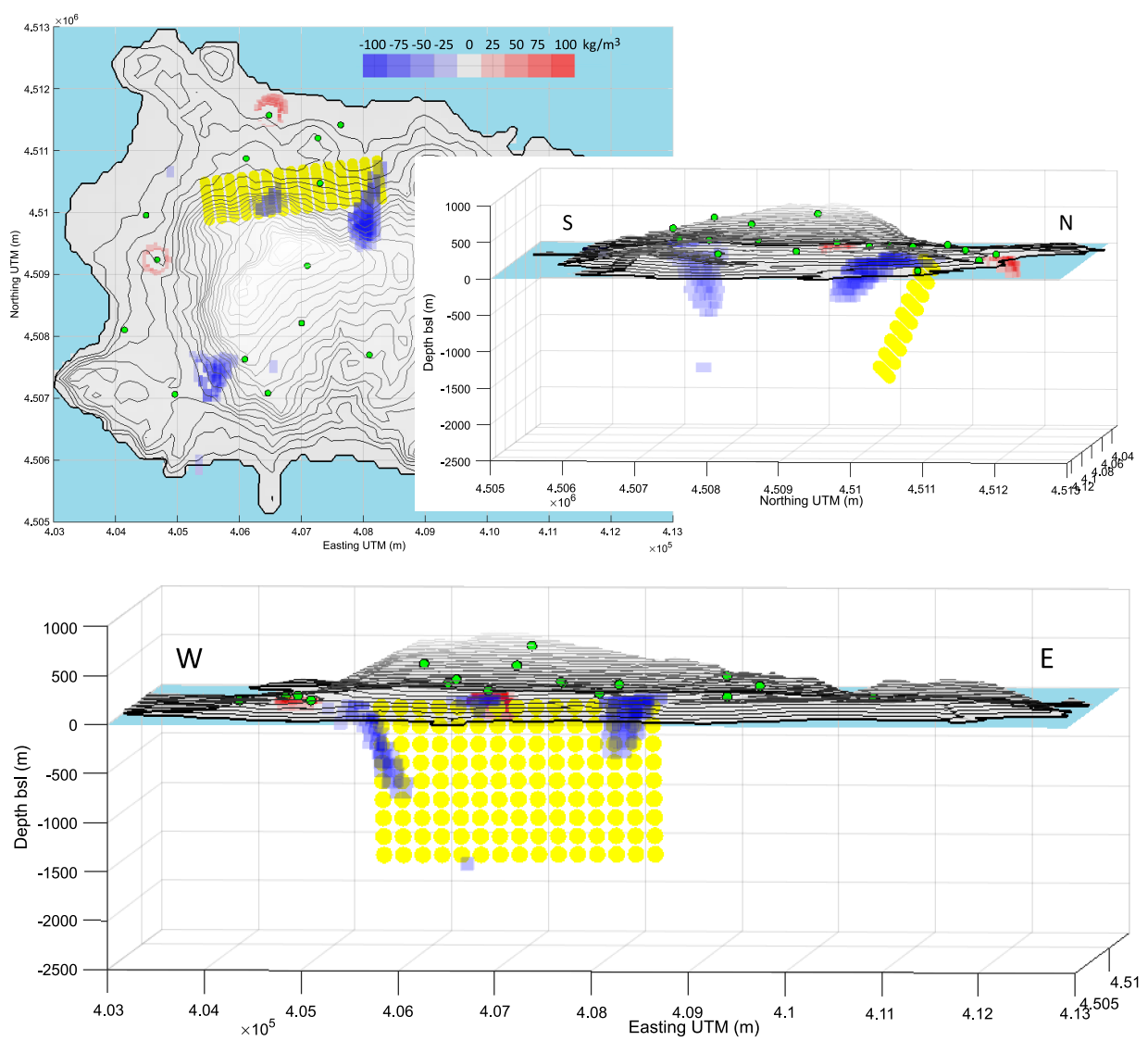

Fig. 9. Top and lateral S-N and $\mathrm{W}-\mathrm{E}$ (side-) views at the resulting 3D inversion model. Blue and red aggregations of prisms represent the sources of negative and positive density change, respectively. Yellow dots represent the earthquake fault plane

terms of its negative mass change and is correlated with the hydrothermal system of the hot springs in the Bagni area. The third source lies in the SW and its position correlates with the boundary of the resurgent block. It extends vertically from sea level to about $1000 \mathrm{~m}$ b.s.l. The negative density change within the volume of the northern sources is interpreted as implying a replacement of the water phase by the steam phase.

Our time-lapse gravity changes are respective to a period of nearly 16 months (29/05/2016 to 22/09/2017). Therefore, the sources of subsurface density changes found by the inversion are also respective to the same pe- 
riod. To interpret them as co-seismic or post-seismic (21 Aug to $22 \mathrm{Sept}$ of 2017) we would have to assume that no subsurface density changes took place between 29 May 2016 and 21 August 2017, which we cannot justify. We would have to rule out any significant hydrological changes in the period 29 May 2016 to 21 Aug 2017. On the other hand, the spatial correlation of the northern sources with the 2017 fault plane might indicate that the found sources are related to the 2017 earthquake and represent a co-seismic or post-seismic perturbation of the hydrothermal system of the island. Moreover, the location of the top of the NE source along the 2017 fault corresponds with the hot springs field of Bagni (Casamicciola).

The geothermal system of the island resides at depths down to $2 \mathrm{~km}$ b.s.l. It consists of high temperature (geothermal gradient of $150-200{ }^{\circ} \mathrm{C} / \mathrm{km}$ ) highly saline fluids percolating along fractures and faults at the boundary of the Mt Epomeo resurgent block and within the porous reworked deposits at the base of this structure (Celico et al., 1999; Chiodini et al., 2004; Carlino et al., 2014; Carlino, 2018; Castaldo et al., 2017; Di Giuseppe et al., 2017; Piscopo et al., 2020). The data obtained from previous investigations suggest that two phase flow (steam + liquid water) is common in the shallow $(\sim 1 \mathrm{~km})$ and high-temperature hydrothermal system of Ischia (Chiodini et al., 2004; Carlino et al., 2014). Additionally, taking into account that the critical point of the water is achieved at $374{ }^{\circ} \mathrm{C}$ and $22 \mathrm{MPa}$ of pressure, assuming for Ischia the average geothermal gradient of $180^{\circ} \mathrm{C} / \mathrm{km}$ and, given the average rock density of about $2100 \mathrm{~kg} / \mathrm{m}^{3}$, the critical condition should be reached at depths between 1.5 and $1.8 \mathrm{~km}$ (Carlino et al., 2014), which corresponds to the 2017 fault bottom. The above observations indicate that the fault surface causing the 2017 earthquake extends from the shallower to the deeper part of the geothermal system (at depths between 0.5 and $2 \mathrm{~km}$ ) and thus the co-seismic displacement likely generated a disturbance of its fluids-thermodynamic condition. For instance, the depressurization due to new cracks of the co-seismic opening could cause a rapid phase change of the critical fluids with its flashing and migration towards the surface. In this case, faulting could have driven the fluids withdrawal and thus fluids overpressure would not have represented the trigger mechanism (Sibson, 1981, 1992).

On the other hand, fluid overpressure could also have driven the rupture process, for instance by breaching a deeper self-sealed zone lubricating 
the fault and triggering the earthquake (Sibson, 1992). In both cases, the found sources (of negative density change) close to the 2017 fault could be interpreted in terms of less dense fluids and/or a vapour phase migration along the fault and their sub-surface output, respectively. Essentially, it is fundamental to understand whether the fluids overpressure represents the actual mechanism triggering the earthquakes or has just a passive role in the earthquake's occurrence at Ischia (Sibson, 1981; Scudieri et al., 2017). Unfortunately, geochemical and hydrological (e.g. water table variation) data of the island are not sufficient to assess whether significant changes within the hydrothermal system of the island have occurred before and after the 2017 event. Detailed studies concerning the diffuse soil gas emissions have been performed in the western and southern sectors of the island (Chiodini et al., 2004; Di Napoli et al., 2011), but a long term and systematic monitoring of fumaroles and hot springs was lacking.

This makes difficult also the interpretation of the found SW source. The position, shape and dip of the SW source implies that it also is related to the boundary of the resurgent block and thus may indicate a pathway for the degassing of magma residing below the resurgent block (Trasatti et al., 2019). As such, it could be interpreted as a post-seismic perturbation of the hydrothermal system in this spot, or a longer term (over our period of 16 months) change in the degassing pattern with the gas phase prevailing over the liquid phase.

It should be also highlighted that variations of temperature and flow rate of fumaroles and hot springs were observed before and after historical earthquakes (e.g. 1881, 1883), as reported by many coeval chronicles of the events (Cubellis and Luongo, 1998 and references therein). Furthermore, co-seismic jet vapour emission along the epicentral area has been also observed during the earthquakes, as in the case of the 1883 event. These observations corroborate the hypothesis that (i) the dynamics of the northern seismogenic fault of the island, which also corresponds to that of the 2021 event (Carlino et al., 2021), has a strong interaction with the hydrothermal system of the island, (ii) the found sources of negative density change along the 2017 fault are likely caused by this interaction.

We have not interpreted nor justified the positive mass changes in the north and west of the island because the isolated (confined to one gravity station) positive gravity changes are observed only at stations ISG12 
(north) and ISG10 (west) that are likely attributable to very local effects of the sites (site effects). Furthermore, these stations are located at the edges of the investigated area and, in particular due to the one at the north, it is not possible to have information on a possible continuation beyond the limits of the island, since the network is limited to the emerged part of the island.

\section{Discussion and conclusions}

We investigated the character of the DITE field due to the co-seismic vertical displacement field caused by the destructive earthquake of 21 August 2017 on the Ischia island. It turns out that this DITE field can be adequately and accurately approximated by its planar Bouguer representation (Eq. (5)). This finding is in agreement with expectations that follow from numerical simulations of (Vajda et al., 2019) due to the shape of the relief on Ischia and due to the spatial character of the deformation field. As a consequence, the gravitational effect of elevation changes observed at gravity benchmarks can be computed accurately enough by multiplying these elevation changes by the Bouguer-corrected normal Free-Air Gradient (BCFAG), the value of which, taking into account the representative constant reference topographic density of $2200 \mathrm{~kg} / \mathrm{m}^{3}$, is $-216.6 \mu \mathrm{Gal} / \mathrm{m}$.

The residual spatiotemporal (time-lapse) gravity changes respective to the period 29/05/2016-22/09/2017 were computed by correcting the observed gravity changes for the Bouguer effect (Eq. (5)) of the elevation changes at gravity benchmarks that occurred over the same period.

The interpreted residual gravity changes have high noise-to-signal ratio and are sparse. Such cases are quite often encountered in 4D microgravimetry, particularly in volcano gravimetry. In spite of this limitation we believe that once the data were collected, one should try to mine for useful information or indications even in such data, yet clearly stating the weak points (limitations) and uncertainties (possible ambiguities) of the presented interpretation.

Due to the time span of nearly 16 months, the residual gravity changes are not purely co-seismic. They contain in terms of "signal content" the effect of subsurface density changes that took place prior to the earthquake, i.e. between the first survey and the earthquake ("pre-seismic changes"), 
those that accompanied the quake ("co-seismic changes") as well as those following the quake, taking place between the quake and the second survey ("post-seismic changes"). Moreover, the sum of these changes is only sensed as the difference between the state at the second survey and the state at the first survey. Such is the nature of time-lapse gravimetry. This limitation can only be overcome by employing continuous microgravimetry, which was not available for the 2017 earthquake.

Since the gravity changes were not corrected for hydrological effects, the residual gravity changes are expected to potentially contain the following signal components: Gravitational effect of co-seismic structural changes, gravitational effect of structural changes due to long-term ongoing subsidence, gravitational effect of hydrological and hydrothermal system changes.

The residual gravity changes at benchmarks of the gravimetric network were inverted by a model exploration and growing source bodies of free geometry inversion approach using the Growth-dg tool. Three main sources of subsurface negative density changes were identified by the inversion method. The time-lapse gravity changes observed over the period of roughly 16 months $(29 / 05 / 2016$ to $22 / 09 / 2017)$ do not allow us to make definite inferences about the co-seismic subsurface fluid changes, because they are affected by the change in the hydrological situation (as well as the change within the hydrothermal system) over the whole 16 month period. However, the spatial correlation of the found two northern sources of negative density change with the location of the earthquake fault plane indicate that the 2017 destructive earthquake caused a disturbance of the hydrothermal system associated with the hot springs at Bagni, which even one month after the earthquake can be seen as a negative density change within the volume of the northern sources implying a replacement of the water phase by the steam phase. A similar cause may be ascribed to the negative density change source in the SW, although it is difficult to interpret this source as co-seismic or post-seismic. The position, shape and dip of the SW source implies that it also is related to the boundary of the resurgent block and thus may indicate another pathway for the degassing of magma residing below the resurgent block (Trassatti et al., 2019).

Our study hypothesizes that the dynamics of the northern seismogenic fault zone has a strong interaction with the hydrothermal system of the island. As a final remark, a detailed study of the Ischia hydrogeological 
system and a systematic monitoring of the island fumaroles and hot springs could provide new insights about the relationship between earthquake occurrence and fluid-dynamics. This would also improve the assessment of the mechanism leading to damaging earthquakes at Ischia and the related hazard.

Acknowledgements. P.V. was supported by the Slovak Research and Development Agency under the contract (project) No. APVV-16-0482 (acronym LITHORES) and by the VEGA grant agency under project No. 2/0006/19. P.Z. and J.P. were supported by the Slovak Research and Development Agency under the contract (project) No. APVV-19-0150 (acronym ALCABA) and the VEGA grant agency under project 2/0100/20. A.G.C. has been supported by the Spanish Ministerio de Ciencia, Innovación and Universidades research project DEEP-MAPS (RTI2018-093874-B-I00). We thank Dr. R. Mari from "Città Metropolitana di Napoli - Direzione Strutturazione e Pianificazione dei servizi Pubblici di interesse generale di Ambito Metropolitano - Ufficio S.I.T. - Sistema Informativo Territoriale" for kindly providing LAS data for the DEM. We express special thanks to Giuseppe Ricciardi and Vincenzo d'Errico for the execution of the gravimetric field surveys.

\section{References}

Acocella V., Funiciello R., 1999: The interaction between regional and local tectonics during resurgent doming: the case of the island of Ischia, Italy. J. Volcanol. Geotherm. Res., 88, 1-2, 109-123, doi : 10.1016/S0377-0273(98)00109-7.

Azzaro R., Del Mese S., Graziani L., Maramai A., Martini G., Paolini S., Screpanti A., Verrubbi V., Arcoraci L., Tertulliani A., 2017: QUEST-Rilievo macrosismico per il terremoto dell'isola di Ischia del 21 agosto 2017 - Rapporto finale. Internal report, doi: 10.5281/zenodo. 886047 (in Italian).

Battaglia M., Gottsmann J., Carbone D., Fernández J., 2008: 4D volcano gravimetry. Geophysics, 73, 6, WA3-WA18, doi: 10.1190/1.2977792.

Berrino G., 1995: Absolute gravimetry and gradiometry on active volcanoes of Southern Italy. Boll. di Geofis. Teor. ed Appl., 37, 146, 131-144.

Berrino G., 2020: The state of the art of gravimetry in Italy. Rend. Fis. Acc. Lincei, ISSN 2037-4631, Special Issue "Earth's gravity field and Earth sciences", 31, 1, 35-48, doi: $10.1007 / \mathrm{s} 12210-020-00924-8$.

Berrino G., Corrado G., 2008: 1981-2007 gravity monitoring of Italian volcanoes. Proceedings of the International Symposium on Terrestrial Gravimetry: Static and Mobile Measurements (TG-SMM2007), 20-24 Agosto 2007, Saint Petersburg (Russia), ISBN 978-5-900780-76-4, 208-212.

Berrino G., Corrado G., Luongo G., Toro B., 1984: Ground deformation and gravity changes accompanying the 1982 Pozzuoli uplift. Bull. Volcanol., 47, 2, 187-200, doi: 10.1007/BF01961548. 
Berrino G., Corrado G., Lo Bascio A., Luongo G., 1985: Variazioni di gravità nell'area vulcanica napoletana (Campi Flegrei, Ischia, Vesuvio). Proceedings of the $4^{\circ} \mathrm{Na}-$ tional Meeting of Gruppo Nazionale Geofisica della Terra Solida CNR, pp. 685-695 (in Italian).

Berrino G., Rymer H., Brown G. C., Corrado G., 1992: Gravity-height correlations for unrest at calderas. J. Volcanol. Geotherm. Res., 53, 1-4, 11-26, doi : 10.1016/03770273(92) 90071-K.

Berrino G., Marson I., Orlando L., Balestri L., Balia R., Bonci L., Bozzo E., Carrozzo M. T., Cerutti G., Cesi C., Ciminale M., Crespi M., De Maria P., Ferri F., Loddo M., Luzio D., Pinna E., Rossi A., 1995: Rete gravimetrica Italiana di ordine zero. Stato di avanzamento. Atti del $14^{\circ}$ Convegno Nazionale Gruppo Nazionale di Geofisica della Terra Solida, 453-465 (in Italian).

Berrino G., Corrado G., Riccardi U., 1998: Sea gravity data in the Gulf of Naples: a contribution to delineating the structural pattern of the Vesuvian area. J. Volcanol. Geotherm. Res.,, 82, 1-4, 139-150, doi: 10.1016/S0377-0273(97)00061-9.

Berrino G., d'Errico V., Ricciardi G., 2013: Thirty years of precise gravity measurements at Mt. Vesuvius: An approach to detect underground mass movements. Ann. Geophys., 56, 4, S0436, doi: 10.4401/ag-6442.

Braun T., Famiani D., Cesca S., 2018: Seismological constraints on the source mechanism of the damaging seismic event of 21 august 2017 on Ischia Island (Southern Italy). Seismil. Res. Lett., 89, 5, 1741-1749, doi : 10.1785/0220170274.

Calderoni G., Di Giovambattista R., Pezzo G., Albano M., Atzori S., Tolomei C., Ventura G., 2019: Seismic and Geodetic Evidences of a Hydrothermal Source in the Md 4.0, 2017, Ischia earthquake (Italy). J. Geophys. Res. Solid Earth, 124, 5, 5014-5029, doi: $10.1029 / 2018$ JB016431.

Camacho A. G., Fernández J., Gottsmann J., 2011: The 3-D gravity inversion package GROWTH2.0 and its application to Tenerife Island, Spain. Comput. Geosci., 37, 4, 621-633, doi: 10.1016/j. cageo.2010.12.003.

Camacho A. G., Prieto J. F., Aparicio A., Ancochea E., Fernández J., 2021a: Upgraded GROWTH 3.0 software for structural gravity inversion and application to El Hierro (Canary Islands). Comput. Geosci., 150, 104720, doi: 10.1016/j.cageo.2021.10 4720.

Camacho A. G., Vajda P., Miller C. A., Fernández J., 2021b: A free-geometry geodynamic modelling of surface gravity changes using Growth-dg software. Sci. Rep., 11, 23442, doi: $10.1038 / s 41598-021-02769-z$.

Capuano P., De Matteis R., Russo G., 2015: The structural setting of the Ischia Island Caldera (Italy): first evidence from seismic and gravity data. Bull. Volcanol., 77, 79, doi: 10.1007/s00445-015-0965-4.

Carbone D., Poland M. P., Diament M., Greco F., 2017: The added value of time-variable microgravimetry to the understanding of how volcanoes work. Earth-Sci. Rev., 169, 146-179, doi: 10.1016/j .earscirev.2017.04.014.

Carlino S., Cubellis E., Marturano A., 2010: The catastrophic 1883 earthquake at the island of Ischia (southern Italy): macroseismic data and the role of geological conditions. Nat. Hazards, 52, 1, 231-247, doi : 10.1007/s11069-009-9367-2. 
Carlino S., Somma R., Troiano A., Di Giuseppe M. G., Troise C., De Natale G., 2014: The geothermal system of Ischia Island (southern Italy): Critical review and sustainability analysis of geothermal resource for electricity generation. Renew. Energy, 62, 177-196, doi: 10.1016/j.renene.2013.06.052.

Carlino S., 2018: Heat flow and geothermal gradients of the Campania region (Southern Italy) and their relationship to volcanism and tectonics. J. Volcanol. Geotherm. Res., 365, 23-37, doi: 10.1016/j.jvolgeores.2018.10.015.

Carlino S., Pino N. A., Tramelli A., De Novellis V., Convertito V., 2021: A common source for the destructive earthquakes in the volcanic island of Ischia (Southern Italy): insights from historical and recent seismicity. Nat. Hazards, 108, 177-201, doi: $10.1007 / \mathrm{s} 11069-021-04675-z$.

Castaldo R., Gola G., Santilano A., De Novellis V., Pepe S., Manzo M., Manzella A., Tizzani P., 2017: The role of thermo-rheological properties of the crust beneath Ischia Island (Southern Italy) in the modulation of the ground deformation pattern. J. Volcanol. Geotherm. Res., 344, 154-173, doi: 10.1016/j.jvolgeores.2017.03.003.

Celico P., Stanzione D., Esposito L., Formica F., Piscopo V., De Rosa B. M., 1999: La complessita idrogeologica di un'area vulcanica attiva; l'Isola d'Ischia (Napoli, Campania). Boll. Soc. Geol. Ital., 118, 3, 485-504 (in Italian).

Chiodini G., Avino R., Brombach T., Caliro S., Cardellini C., De Vita S., Frondini F., Granirei D., Marotta E., Ventura G., 2004: Fumarolic and diffuse soil degassing west of Mount Epomeo, Ischia, Italy. J. Volcanol. Geotherm. Res., 133, 1-4, 291-309, doi : 10.1016/S0377-0273(03)00403-7.

Cubellis E., Luongo G., 1998: Il terremoto del 28 luglio 1883 a Casamicciola nell'Isola d'Ischia. Presidenza del Consiglio dei Ministri - Servizio Sismico Nazionale, Rome, Italy (in Italian).

Dehant V., Defraigne P., Wahr J. M., 1999: Tides for a convective Earth. J. Geophys. Res. Solid Earth, 104 B1, 1035-1058, doi: 10.1029/1998JB900051.

De Martino P., Tammaro U., Obrizzo F., Sepe V., Brandi G., D'Alessandro A., Dolce M., Pingue F., 2011: La rete GPS dell'isola di Ischia: deformazioni del suolo in un'area vulcanica attiva (1998-2010)). Quad. di Geofis., 95, 1-61, ISSN 1590-2595 (in Italian with English summary).

De Novellis V., Carlino S., Castaldo R., Tramelli A., De Luca C., Pino N. A., Pepe S., Convertito V., Zinno I., De Martino P., Bonano M., Giudicepietro F., Casu F., Macedonio G., Manunta M., Cardaci C., Manzo M., Di Bucci D., Solaro G., Zeni G., Lanari R., Bianco F., Tizzani P., 2018: The 21 august 2017 Ischia (Italy) earthquake source model inferred from seismological, GPS, and DInSAR measurements. Geophys. Res. Lett., 45, 5, 2193-2202, doi: 10.1002/2017GL076336.

Del Gaudio C., Aquino I., Ricco C., Sepe V., Serio C., 2011: Monitoraggio geodetico dell'isola d'Ischia: risultati della livellazione geometricadi precisione eseguita a Giugno 2010. Quad. di Geofis., 87, 1-20, ISSN 1590-2595 (in Italian with English summary).

Devoti R., De Martino P., Pietrantonio G., Dolce M., 2018: Coseismic displacements on Ischia island, real-time GPS positioning constraints on earthquake source location. Ann. Geophys., 61, 3, SE337, doi: 10.4401/ag-7656. 
Di Giuseppe M. G., Troiano A., Carlino S., 2017: Magnetotelluric imaging of the resurgent caldera on the island of Ischia (southern Italy): inferences for its structure and activity. Bull. Volcanol., 79, 12, 85, doi: 10.1007/s00445-017-1170-4.

Di Napoli R., Martorana R., Orsi G., Aiuppa A., Camarda M., De Gregorio S., Gagliano Candela E., Luzio D., Messina N., Pecoraino G., Bitetto M., de Vita S., Valenza M., 2011: The structure of a hydrothermal system from an integrated geochemical, geophysical, and geological approach: The Ischia Island case study. Geochem. Geophys. Geosyst., 12, 7, doi : 10.1029/2010GC003476.

EMERGEO Working Group, Nappi R., Alessio G., Belviso P., Gaudiosi G., Marotta E., Nave R., Peluso R., Siniscalchi V., Civico R., Pizzimenti L., Porfido S., 2017: The August 21, 2017 Isola di Ischia (Casamicciola) Earthquake: Coseismic Effects. Zenodo, doi: $10.5281 /$ zenodo. 1003188 .

ESRI, 2011: ArcGIS Desktop: Release 10; Environmental Systems Research Institute, Inc., Redlands, CA, USA.

Fernández J., Pepe A., Poland M. P., Sigmundsson F., 2017: Volcano Geodesy: Recent developments and future challenges. J. Volcanol. Geotherm. Res., 344, 1-12, doi : 10.1016/j.jvolgeores.2017.08.006.

Hayford J. F., Bowie W., 1912: The effect of topography and isostatic compensation upon the intensity of gravity. U.S. Coast and Geodetic Survey, Washington, DC, Special Publication No. 10.

Hemmings B., Gottsmann J., Whitaker F., Coco A., 2016: Investigating hydrological contributions to volcano monitoring signals: a time-lapse gravity example. Geophys. J. Int., 207, 1, 259-273, doi: 10.1093/gji/ggw266.

Manzo M., Ricciardi G. P., Casu F., Ventura G., Zeni G., Borgstroem S., Berardino V., Del Gaudio C., Lanari R., 2006: Surface deformation analysis in the Ischia Island (Italy) based on spaceborne radar interferometry. J. Volcanol. Geotherm. Res., 151, 4, 399-416, doi: 10.1016/j.jvolgeores.2005.09.010.

Nappi R., Alessio G., Gaudiosi G., Nave R., Marotta E., Siniscalchi V., Civico R., Pizzimenti L., Peluso R., Belviso P., Porfido S., 2018: The 21 august 2017 md 4.0 Casamicciola earthquake: first evidence of Coseismic Normal surface faulting at the Ischia Volcanic Island. Seismol. Res. Lett., 89, 4, 1323-1334. doi : 10.1785/0220180063.

Pingue F., Berrino G., Capuano P., Obrizzo F., De Natale G., Esposito T., Serio C., Tammaro U., De Luca G., Scarpa R., Troise C., Corrado G., 2000: Ground deformation and gravimetric monitoring at Somma-Vesuvius and in the Campanian volcanic area (Italy). Phys. Chem. Earth, 25, 9-11, 747-754, doi: 10.1016/S1464-1895(00) 001 16-2.

Piscopo V., Lotti F., Formica F., Lana L., Pianese L., 2020: Groundwater flow in the Ischia volcanic island (Italy) and its implications for thermal water abstraction. Hydrogeol. J., 28, 2, 579-601, doi: 10.1007/s10040-019-02070-4.

Ricco C., Augusti V., Scarpato G., Aquino I., 2017: La deformazione del suolo ad Ischia rilevata dalla Rete tiltmetrica. Blog INGVterremoti, accessible at https://ingvter remoti.com/2017/12/12/la-deformazione-del-suolo-ad-ischia-rilevata-dall a-rete-tiltmetrica/ (in Italian). 
Ricco C., Aquino I., Augusti V., D'Auria L., Del Gaudio C., Scarpato G., 2018: Improvement and development of the tiltmetric monitoring networks of Neapolitan volcanoes. Ann. Geophys., 61, 1, SE114, doi: 10.4401/ag-7496.

Rymer H., 1994: Microgravity change as a precursor to volcanic activity. J. Volcanol. Geotherm. Res., 61, 3-4, 311-328, doi : 10.1016/0377-0273(94)90011-6.

Selva J., Acocella V., Bisson M., Caliro S., Costa A., Della Seta M., De Martino P., de Vita S., Federico C., Giordano G., Martino S., Cardaci C., 2019: Multiple natural hazards at volcanic islands: a review for the Ischia volcano (Italy). J. Appl. Volcanol., 8, 5, 1-43, doi : 10.1186/s13617-019-0086-4.

Sepe V., Atzori S., Ventura G., 2007: Subsidence due to crack closure and depressurization of hydrothermal systems: a case study from Mt Epomeo (Ischia Island, Italy). Terra Nova, 19, 2, 127-132, doi: 10.1111/j.1365-3121.2006.00727.x.

Sbrana A., Marianelli P., Pasquini G., 2018: Volcanology of Ischia (Italy). J. Maps, 14, 2, 494-503, doi: 10.1080/17445647.2018.1498811.

Scuderi M. M., Collettini C., Marone C., 2017: Frictional stability and earthquake triggering during fluid pressure stimulation of an experimental fault. Earth Planet. Sci. Lett., 477, 84-96, doi: 10.1016/j.epsl.2017.08.009.

Sibson R. H., 1981: Controls on low-stress hydro-fracture dilatancy in thrust, wrench and normal fault terrains. Nature, 289, 5799, 665-667, doi: 10.1038/289665a0.

Sibson R. H., 1992: Implications of fault-valve behaviour for rupture nucleation and recurrence. Tectonophysics, 211, 1-4, 283-293, doi : 10 .1016/0040-1951 (92) 90065-E.

Spratt R. S., 1982: Modelling the effect of atmospheric pressure variations on gravity.s Geophys. J. R. Astron. Soc., 71, 1, 173-186, doi : 10.1111/j.1365-246X.1982.tb0 4991.x.

Tamura Y., 1987: A harmonic development of the tide-generating potential. Bull. Inf. Marées Terrestres, Bruxelles, 99, 6813-6855.

Trasatti E., Acocella V., Di Vito M. A., Del Gaudio C., Weber G., Aquino I., Caliro S., Chiodini G., de Vita S., Ricco C., Caricchi L., 2019: Magma degassing as a source of long-term seismicity at volcanoes: The Ischia island (Italy) case. Geophys. Res. Lett., 46, 24, 14421-14429, doi: 10.1029/2019GL085371.

Vajda P., Zahorec P., Bilčík D., Papčo J., 2019: Deformation-induced topographic effects in interpretation of spatiotemporal gravity changes: Review of approaches and new insights. Surv. Geophys., 40, 5, 1095-1127, doi: 10.1007/s10712-019-09547-7.

Vajda P., Zahorec P., Miller C. A., Le Mével H., Papčo J., Camacho A. G., 2021: Novel treatment of the deformation-induced topographic effect for interpretation of spatiotemporal gravity changes: Laguna del Maule (Chile). J. Volcanol. Geotherm. Res., 414, 107230, doi: 10.1016/j.jvolgeores.2021.107230.

Van Camp M., Vauterin P., 2005: Tsoft: graphical and interactive software for the analysis of time series and Earth tides. Comput. Geosci., 31, 5, 631-640, doi: 10.1016/j.ca geo.2004.11.015.

Van Camp M., de Viron O., Watlet A., Meurers B., Francis O., Caudron C., 2017: Geophysics from terrestrial time-variable gravity measurements. Rev. Geophys., 55, 4, 938-992, doi : 10.1002/2017RG000566. 
Vilardo G., Ventura G., Terranova C., Matano F., Nardò S., 2009: Ground deformation due to tectonic, hydrothermal, gravity, hydrogeological, and anthropic processes in the Campania region (southern Italy) from Permanent Scatterers Synthetic Aperture Radar Interferometry. Remote Sens. Environ., 113, 1, 197-212, doi: 10.1016/j.rse.2008.09.007.

Warburton R. J., Goodkind J. M., 1977: The influence of barometric-pressure variations on gravity. Geophys. J. R. Astron. Soc., 48, 3, 281-292, doi : 10.1111/j.1365-246X. 1977.tb03672.x.

Zahorec P., Marušiak I., Mikuška J., Pašteka R., Papčo J., 2017: Numerical Calculation of Terrain Correction Within the Bouguer Anomaly Evaluation (Program Toposk), chapter 5. In: Pašteka R., Mikuška J., Meurers B. (Eds.): Understanding the Bouguer Anomaly: A Gravimetry Puzzle. Elsevier, ISBN 978-0-12-812913-5, 7992, doi: 10.1016/B978-0-12-812913-5.00004-X. 